\title{
Thrombotic Microangiopathy Following Hypnale zara (Hump-Nosed Pit Viper) Envenoming: The First Known Case Report from Sri Lanka
}

\author{
Rathnayaka Mudiyanselage M.K. Namal Rathnayaka, MBBS, MA, MSc in Medical Tox., Dip. in Tox., Dip. in OH\&S ${ }^{1,2,3}$; \\ P.E. Anusha Nishanthi Ranathunga, $\mathrm{MBBS}^{4}$; Senanayake A.M. Kularatne, MBBS, MD, MRCP (UK), FRCP (Lond) ${ }^{5}$ \\ ${ }^{1}$ Department of Veterinary Pathobiology, Faculty of Veterinary Medicine and Animal Science, University of Peradeniya, Sri Lanka; ${ }^{2}$ Intensive Care Unit/ \\ Anaesthesia, Teaching Hospital, Ratnapura, Sri Lanka; ${ }^{3}$ Clinical Pharmacology and Therapeutics, Postgraduate Institute of Medicine, University of \\ Colombo, Sri Lanka; ${ }^{4}$ Medical Unit Teaching Hospital, Ratnapura, Sri Lanka; ${ }^{5}$ Faculty of Medicine, University of Peradeniya, Sri Lanka
}

\begin{abstract}
A 65-y-old previously healthy farmer developed thrombotic microangiopathy (TMA) comprising the triad of acute kidney injury, microangiopathic haemolysis, and thrombocytopenia after a proven Hypnale zara (hump-nosed pit viper) bite. He developed coagulopathy, which was treated with fresh frozen plasma, and underwent 8 cycles of hemodialysis. He is being followed up in the nephrology clinic for acute kidney injury. TMA caused by Hypnale hypnale, the commonest species of genus Hypnale, has previously been reported, but this is the first known case of TMA following a bite by $H$ zara, the endemic species in Sri Lanka.
\end{abstract}

Keywords: snakebites, microangiopathic hemolysis, coagulopathy, acute kidney injury, hemolytic uremic syndrome, fresh frozen plasma

\section{Introduction}

Hump-nosed pit vipers of the genus Hypnale are the commonest cause of venomous snakebites in Sri Lanka, ${ }^{1}$ accounting for 22 to $77 \%$ of all venomous snakebites. ${ }^{2,3}$ There are 3 species in the genus: $H$ hypnale, $H$ zara, and $H$ nepa. The latter 2 are endemic to Sri Lanka, and the former is found in both Sri Lanka and the Western Ghats of India. ${ }^{4}$ Hump-nosed vipers are encountered all over the island except in the peninsula of Jaffna in the north. Among the 3 species, most bites (80\%) are caused by $H$ hypnale; $15 \%$ are by $H$ zara; and only $5 \%$ of bites are caused by $H$ nepa. ${ }^{5,6} H$ hypnale are more frequently found in anthropogenic habitats, whereas $H$ zara are encountered less frequently in anthropogenic habitats. $H$ nepa inhabit high elevations, $1250 \mathrm{~m}$ above sea level. $H$

Corresponding author: Rathnayaka Mudiyanselage M.K. Namal Rathnayaka, MBBS, MA, MSc in Medical Tox., Dip. in Tox., Dip. in OH\&S, Department of Veterinary Pathobiology, Faculty of Veterinary Medicine and Animal Science, No. 11, Flower Road, New Town Housing Scheme 01, New Town, Ratnapura, Sri Lanka; e-mail: namalrath10@yahoo.com.

Submitted for publication April 2019.

Accepted for publication August 2019. zara are identified by their characteristic prominent snout tip (hump), keeled costal scales, and characteristic color bands in the neck, the very feature emphasized in the local dialect, Sinhala: Wayiran gelathi kunakatuwa. The dorsal ground color of $H$ zara varies according to the geographical region (Figure 1).

Hump-nosed pit viper bites commonly cause local envenomation, such as pain, swelling, necrosis, and blistering. ${ }^{5-7}$ Systemic manifestations such as acute kidney injury (AKI), ${ }^{7,8}$ chronic kidney disease, ${ }^{8-10}$ coagulopathy, ${ }^{5,7}$ microangiopathic hemolysis, ${ }^{11}$ and thrombotic microangiopathy (TMA) ${ }^{12-16}$ may rarely occur after bites. TMA has previously been reported after bites by Hypnale $e^{6,8,12,14,16}$ but has not been documented in $H$ zara or $H$ nepa bites. We report the first known case of TMA after envenomation by $H$ zara in Sri Lanka.

\section{Case Report}

A 65-y-old previously healthy male farmer was transferred from a local hospital for further management of a humpnosed viper bite to his left foot associated with oliguria and increased serum creatinine level of $4.3 \mathrm{mg} \cdot \mathrm{dL}^{-1}$ 
(A)

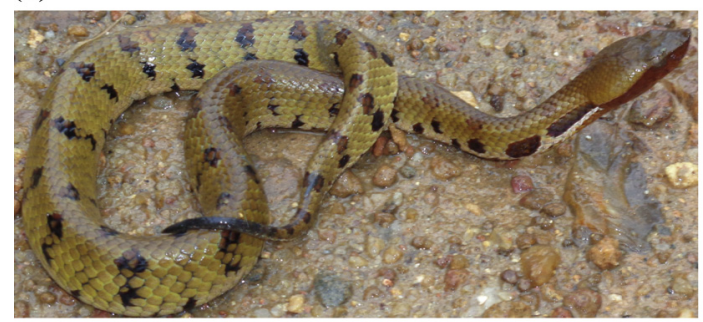

(B)

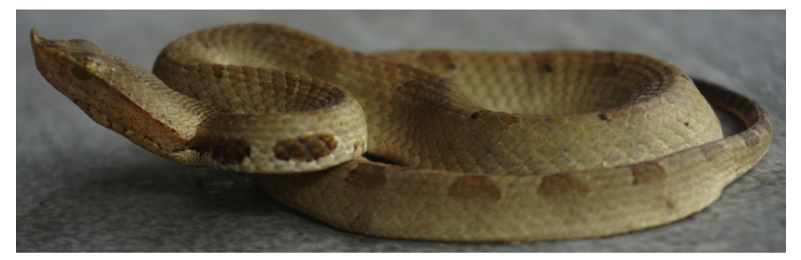

(C)

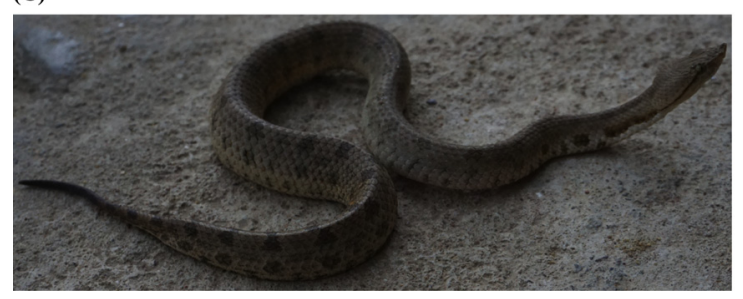

Figure 1. Color variation of adult Hypnale zara in different locations in Ratnapura District (wet zone) $\left(06^{\circ} 40^{\prime} \mathrm{N} 80^{\circ} 24^{\prime} \mathrm{E}\right.$, elevation $130 \mathrm{~m}[430$ $\mathrm{ft}]$ ) in Sri Lanka. A, Balangada. B, Udaniriella. C, Kuruvita. Note the identifying features of $H$ zara: prominent (raised) hump (not found in $H$ hypnale and $H$ nepa), chracteristic color bands in the neck (not found in $H$ hypnale and $H$ nepa), and keeled costal scales (not found in $H$ nepa).

(normal 0.4-1.2). He was educated up to grade 5 and lives at Pallebedda, a remote village in Southeast Ratnapura, Sri Lanka. He was bitten by the snake while he was working in a pepper estate at 0945 and was admitted to a local hospital at around 1150 . He was not given native treatments and the bitten site was not washed, but it was ligated above the site of bite for $30 \mathrm{~min}$. He was treated symptomatically for $1 \mathrm{~d}$ in a local hospital and then transferred with the snake specimen.

On admission to the teaching hospital, he had reduced urine output, moderate pain, and swelling over the foot with a blister on the bitten site (Figure 2). He had not developed necrosis or bleeding from the site of the bite. His blood pressure was 130/70 $\mathrm{mm} \mathrm{Hg}$ and pulse rate was 80 beats $\cdot \min ^{-1}$. Respiratory rate was 15 cycles $\cdot \mathrm{min}^{-1}$, and on air, oxygen saturation was $99 \%$. Examination of respiratory system, nervous system, and abdomen revealed no abnormality. His 20-min whole blood clotting test (WBCT20), done on admission and then at 6-h intervals for $2 \mathrm{~d}$, was positive ( $>20 \mathrm{~min}$ ). Peripheral blood microscopy done on admission (48 h after snakebite) showed normochromic-
(A)

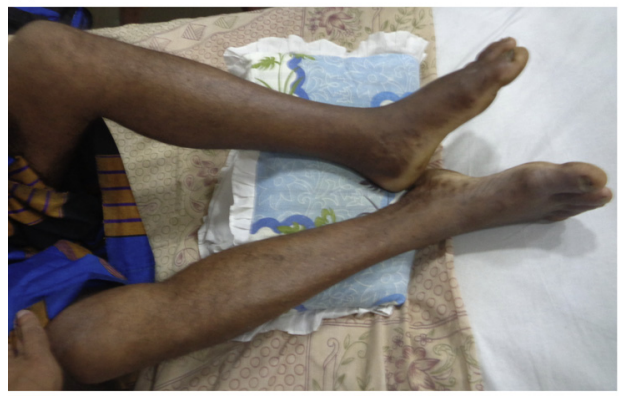

(B)

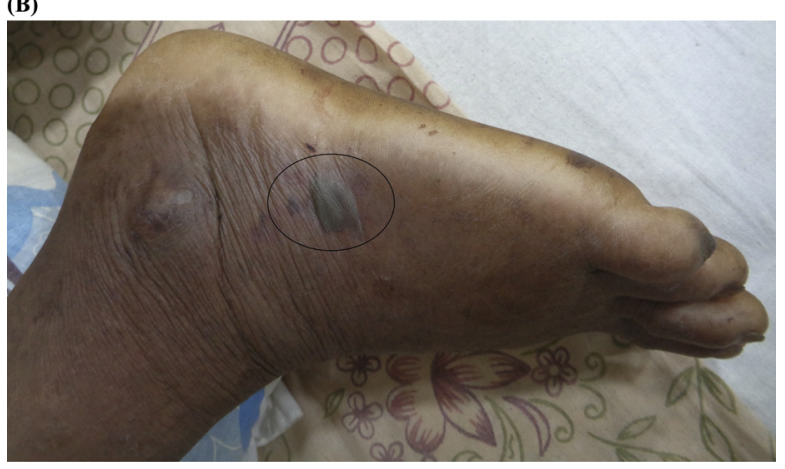

Figure 2. A, Site of bite-left foot on day 2 of snakebite. B, Blister formation (circled).

normocytic red blood cells, many polychromatics, acanthocytes, and fragmented red blood cells ( $>4$ in high-power field), suggestive of microangiopathic hemolytic anemia (MAHA) (Figure 3). The laboratory findings are shown in Table 1. He was treated with 2 packs of fresh frozen plasma (FFP) on day 1. Intravenous cloxacillin $500 \mathrm{mg}$ every $6 \mathrm{~h}$, metronidazole $500 \mathrm{mg}$, and paracetamol $1 \mathrm{~g}$ thrice daily were started. As serum creatinine was gradually increasing (Figure 4) associated with oliguria, hemodialysis was started on day 1 of admission, and subsequently 8 cycles were done. Subcutaneous erythropoietin $4000 \mathrm{U}$ was administered every other day.

On day 2 of admission, because the patient had high blood pressure (initially 160/100 $\mathrm{mm} \mathrm{Hg}$ ) amlodipine 5 mg twice a day was started, and his $2 \mathrm{D}$ echocardiogram was normal (ejection fraction $>60 \%$ ). Lactate dehydrogenase level on day 8 was $1129 \mathrm{IU} \cdot \mathrm{I}^{-1}$ (normal 200-400). He was discharged on day 15 after urine output normalized, and follow-up with the nephrology unit was arranged. According to the key, ${ }^{4}$ the snake was identified as $\mathrm{H}$ zara (Figure 5) with characteristic identifying features (Figure 5B and 5C).

At clinic follow-up on day 20, serum creatinine and blood urea were $872 \mu \mathrm{mol} \cdot \mathrm{L}^{-1}$ and $24 \mathrm{mmol} \cdot \mathrm{L}^{-1}$, respectively, for which 1 cycle of hemodialysis was performed. Twenty-seven days after the snakebite, serum creatinine and blood urea were $525 \mu \mathrm{mol} \cdot \mathrm{L}^{-1}$ and $3 \mathrm{mmol} \cdot \mathrm{L}^{-1}$, 
(A)

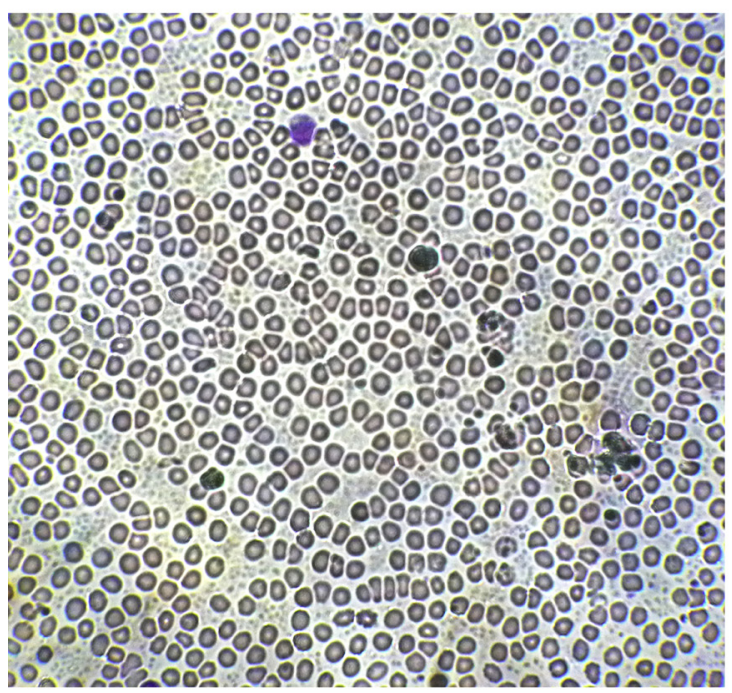

(B)

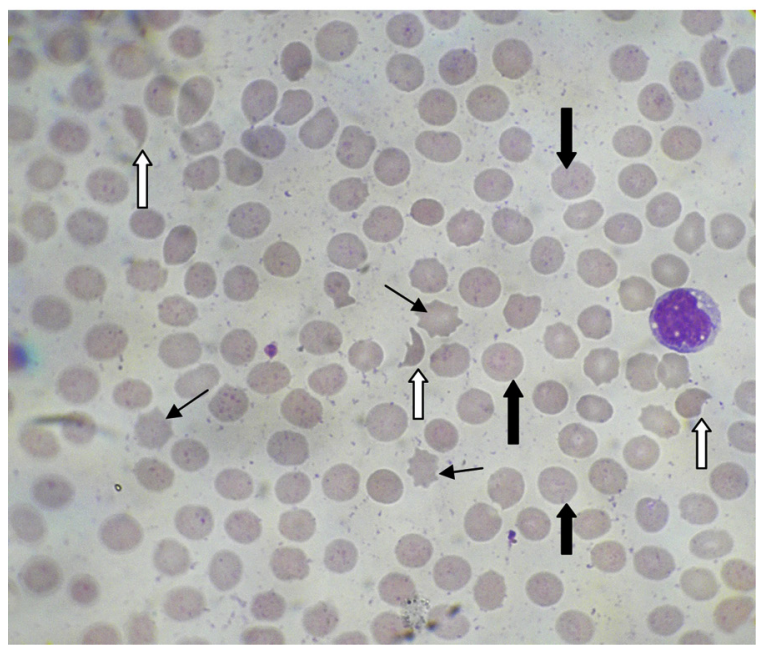

Figure 3. Peripheral blood microcopy showing microangiopathic hemolysis on day 2 of snakebite. Note that white arrows indicate fragmented erythrocytes (schistocytes), wide black arrows indicate polychromatics, and acanthocytes are indicated by thin black arrows. A, x40. B, x100.

respectively. Blood urea nitrogen was $26 \mathrm{mg} \cdot \mathrm{dL}^{-1}$ (normal 4.7-23), and renal ultrasonography showed features of renal parenchymal disease (Figure 6).

\section{Discussion}

TMA, which is the triad of AKI, MAHA, and thrombocytopenia, is a known complication of hump-nosed viper envenomation $^{6,8,12-16}$ and occurs in 3 to $5 \%$ of all Hypnale bites. ${ }^{6,17}$ Microangiopathic hemolysis occurs in $7 \%$ of patients with Hypnale bites, ${ }^{6,17}$ and all 3 species of genus Hypnale cause MAHA, ${ }^{6,11}$ which is diagnosed from the presence of more than 3 fragmented red blood cells (schistocytes) in a high-power field on peripheral blood microscopy. Our patient had more than 4 fragmented red blood cells in a high-power field on day 3 of snakebite, reduced hemoglobin level since day 2 of snakebite, and increased lactate dehydrogenase level measured on day 8 of bite, which are all suggestive of intravascular hemolysis. However, intravascular hemolysis may also occur due to red blood cell lysis caused by phospholipase $\mathrm{A}_{2}$ in Hypnale venom. Both microangiopathic hemolysis and hemolysis due to phospholipase $A_{2}$ are intravascular and cause elevation of retic count $>2 \%$, indirect bilirubin, lactate dehydrogenase, urinary urobilinogen, and aspartate aminotransferase $>$ alanine aminotransferase. In addition, there is a reduction in the hemoglobin level in these patients, thereby resulting in anemia. These 2 types of hemolysis can be differentiated on peripheral blood microscopy (blood picture) by the presence of fragmented red cells (schistocytes) in microangiopathic hemolysis.

$H$ zara frequently cause local envenomation, such as pain, swelling, necrosis, blistering, and lymphadenopathy, ${ }^{5,6}$ but rarely cause systemic manifestations such as AKI, coagulaopathy, and MAHA. ${ }^{6,11,17,18}$ However, death may occur as a result of $H$ zara envenomation. ${ }^{18}$ On admission to the teaching hospital (day 2 following snakebite) our patient had coagulopathy detected from WBCT20 and marginally elevated clotting profile [prothrombin time (PT)/international normalized ratio (INR) and activated partial thromboplastin time (APTT)]. Therefore, 2 packs of FFP were administered. Antivenom is the best treatment for snake envenoming, but because no antivenom is currently available for Hypnale bites, FFP therapy is an option in managing coagulopathy. In Russell's viper and Australian Elapid bites, early administration of FFP within $4 \mathrm{~h}$ of starting antivenom is found to be beneficial. ${ }^{19,20}$ FFP is cheap, readily available, and easily accessible in many resource-poor countries such as Sri Lanka. It contains almost all clotting factors. Cryoprecipitate is a rich source of fibrinogen, and it contains factor VIII, XIII, and von Willebrand factor, but there are some risks with use in venom-induced consumption coagulopathy (VICC).

Theoretically, clotting factor replacement should correct coagulopathy in the absence of venom-induced clotting factor consumption. In Hypnale envenomation, however, in the absence of antivenom, there is persistent, ongoing clotting factor consumption; factor replacement may worsen the state of coagulopathy because more substrate will be available for the procoagulant toxins to activate and elevate the levels of degradation products. This may accelerate the hyperfibrinolytic state and increase the risk of bleeding. On the other hand, fatalities may occur with FFP therapy when 
Table 1. Laboratory findings during hospital stay

\begin{tabular}{|c|c|c|c|c|c|c|c|c|c|c|c|c|c|c|c|}
\hline \multirow[t]{2}{*}{ Measure } & \multirow{2}{*}{$\begin{array}{l}\text { Reference } \\
\text { range }\end{array}$} & \multicolumn{14}{|l|}{ Day } \\
\hline & & 1 & 2 & 3 & 4 & 5 & 6 & 7 & 8 & 9 & 10 & 11 & 12 & 13 & 14 \\
\hline $\mathrm{WBC}\left(\mathrm{x} 10^{3} \cdot \mu \mathrm{L}^{-1}\right)$ & $4-10$ & 12 & 9 & 7 & 7 & 8 & 8 & 8 & 11 & 9 & 12 & 13 & 15 & 11 & 9 \\
\hline Neutrophils (\%) & $50-70$ & 86 & 81 & 72 & 73 & 66 & 71 & 68 & 76 & 75 & 75 & 82 & 79 & 79 & 73 \\
\hline Lymphocytes (\%) & $20-40$ & 6 & 9 & 13 & 13 & 16 & 11 & 14 & 11 & 11 & 12 & 9 & 11 & 10 & 11 \\
\hline Neutrophil count $\left(\mu \mathrm{L}^{-1}\right)$ & $2000-7000$ & 11000 & 7600 & 4600 & 5200 & 5000 & 6000 & 5500 & 8000 & 7000 & 9000 & 11000 & 12000 & 8800 & 7000 \\
\hline Lymphocyte count $\left(\mu \mathrm{L}^{-1}\right)$ & $800-4000$ & 800 & 800 & 900 & 1000 & 1200 & 900 & 1200 & 1200 & 1000 & 1400 & 1000 & 1600 & 1000 & 1000 \\
\hline Platelets $\left(\times 10^{3} \cdot \mu \mathrm{L}^{-1}\right)$ & $150-400$ & 75 & 63 & 66 & 78 & 95 & 113 & 125 & 187 & 217 & 247 & 261 & 267 & 235 & 225 \\
\hline $\mathrm{Hb}\left(\mathrm{g} \cdot \mathrm{dL}^{-1}\right)$ & $11-16$ & 11.4 & 9.3 & 7.9 & 8.0 & 8.3 & 7.5 & 7.2 & 8.1 & 7.7 & 8.5 & 8.2 & 8.1 & 7.2 & 7.4 \\
\hline $\mathrm{RBC}$ count $\left(10^{6} \cdot \mu \mathrm{L}^{-1}\right)$ & $3.5-5.5$ & 3.8 & 3.2 & 2.6 & 2.8 & 2.9 & 2.6 & 2.5 & 2.7 & 2.6 & 2.9 & 2.8 & 2.8 & 2.6 & 2.5 \\
\hline $\operatorname{PCV}(\%)$ & $37-54$ & 34 & 29 & 23 & 25 & 25 & 23 & 22 & 24 & 24 & 26 & 25 & 25 & 23 & 22 \\
\hline $\mathrm{PT}(\mathrm{s})$ & $10-15$ & $17.8 / 12$ & $14 / 12$ & $12.9 / 12$ & $13 / 12$ & & & & & & & & $14 / 12$ & & \\
\hline INR & $1.0-1.4$ & 1.5 & 1.2 & 1.1 & 1.1 & & & & & & & & 1.2 & & \\
\hline $\operatorname{APTT}(\mathrm{s})$ & $25-30$ & $36.4 / 25$ & $36 / 25$ & $32 / 25$ & & & & & & & & & & & \\
\hline $\mathrm{Na}^{+}\left(\mathrm{mmol} \cdot \mathrm{L}^{-1}\right)$ & $135-145$ & 135 & 134 & 134 & 139 & 137 & & 140 & & 139 & 135 & 131 & 137 & 134 & 136 \\
\hline $\mathrm{K}^{+}\left(\mathrm{mmol} \cdot \mathrm{L}^{-1}\right)$ & $3.5-4.5$ & 3.9 & 3.9 & 3.3 & 3.3 & 3.1 & & 3.5 & & 3.7 & 3.4 & 3.3 & 3.5 & 3.6 & 3.6 \\
\hline Blood urea $\left(\mathrm{mmol} \cdot \mathrm{L}^{-1}\right)$ & $7.8-20.1$ & 17 & 18 & 8 & 4 & 3 & 3 & 4 & 6 & 7 & 10 & 11 & 6 & 8 & 6 \\
\hline Creatinine $\left(\mu \mathrm{mol} \cdot \mathrm{L}^{-1}\right)$ & $60-115$ & 563 & 506 & 389 & 279 & 265 & 222 & 290 & 477 & 572 & 663 & 709 & 522 & 626 & 417 \\
\hline SGOT (AST) $\left(\mathrm{U} \cdot \mathrm{L}^{-1}\right)$ & $0-35$ & 70 & 26 & & 31 & & & & & & & & 17 & 16 & \\
\hline SGPT (ALT) $\left(\mathrm{U} \cdot \mathrm{L}^{-1}\right)$ & $0-45$ & 31 & 27 & & 23 & & & & & & & & 20 & 16 & \\
\hline MCV (fL) & $80-100$ & 90 & 89 & 88 & 90 & 88 & 88 & 89 & 88 & 91 & 89 & 89 & 89 & 91 & 88 \\
\hline $\mathrm{MCH}\left(\mathrm{pg} \cdot \mathrm{cell}^{-1}\right)$ & $27-34$ & 30 & 29 & 30 & 29 & 29 & 29 & 29 & 29 & 30 & 29 & 29 & 28 & 28 & 29 \\
\hline $\operatorname{MCHC}\left(\mathrm{g} \cdot \mathrm{dL}^{-1}\right)$ & $32-36$ & 33 & 32 & 34 & 32 & 33 & 33 & 33 & 33 & 32 & 33 & 32 & 32 & 31 & 33 \\
\hline MPV (fL) & $7.8-11.0$ & 8.4 & 9.0 & 9.0 & 9.3 & 9.0 & 9.2 & 9.0 & 8.4 & 8.2 & 7.8 & 7.6 & 7.7 & 7.9 & 7.7 \\
\hline $\mathrm{CRP}\left(\mathrm{mg} \cdot \mathrm{L}^{-1}\right)$ & $<6$ & 54 & & & & & & & & & & & & & \\
\hline Blood picture & & MAHA & & & & & MAHA & & & & & & & & \\
\hline WBCT20 & $<20$ min & $>20 \mathrm{~min}$ & $>20 \mathrm{~min}$ & $<20$ min & & & & & & & & & & & \\
\hline
\end{tabular}

WBC, white blood cells; Hb, hemoglobin; RBC, red blood cells; PCV, packed cell volume; PT, prothrombin time; INR, international normalized ratio; APTT, activated partial thromboplastin time; SGOT, serum glutamic-oxaloacetic transaminase; AST, aspartate aminotransferase; SGPT, serum glutamic-pyruvic transaminase; ALT, alanine aminotransferase; MCV, mean corpuscular volume; MCH, mean corpuscular hemoglobin; MCHC, mean corpuscular hemoglobin concentration; MPV, mean platelet volume; CRP, C-reactive protein; MAHA, microangiopathic hemolytic anemia; WBCT20, 20 min whole blood clotting test. 


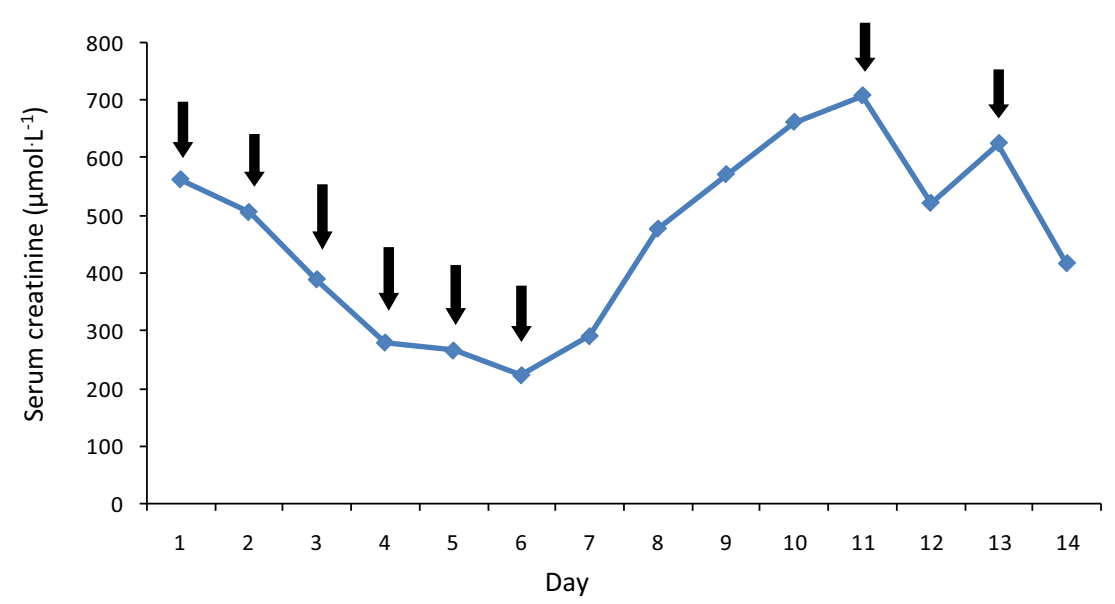

Figure 4. Daily changes in serum creatinine levels with hemodialysis. Note that black arrows indicate the points of hemodialysis.

(A)

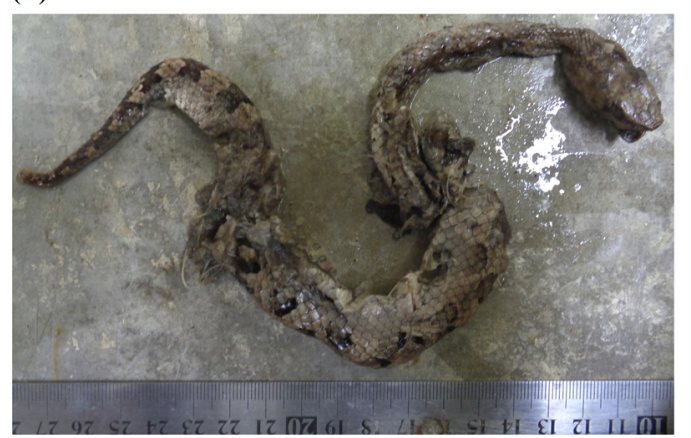

(B)

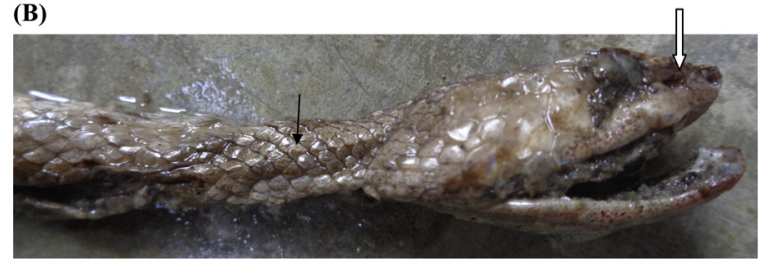

(C)

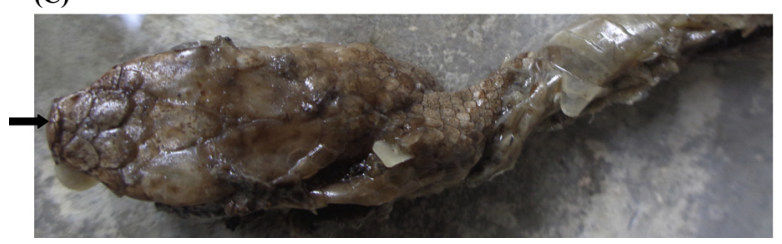

Figure 5. A, Snake responsible for the bite-Hypnale zara (hump-nosed pit viper), adult female snake whose total length is $354 \mathrm{~mm}$, head length is $30 \mathrm{~mm}$, tail length is $52 \mathrm{~mm}$, snout to vent length is $302 \mathrm{~mm}$. From Southeast Ratnapura region $\left(06^{\circ} 40^{\prime} \mathrm{N} 80^{\circ} 24^{\prime} \mathrm{E}\right.$, elevation $130 \mathrm{~m}$ [430 ft]), Sri Lanka. B, note the keeled costal scales, indicated by thin black arrow, and $(\mathrm{C})$ the prominent tip of the snout (hump), indicated with wide black arrow, are the identifying features that distinguish $H$ zara from $H$ hypnale and $H$ nepa. White arrow in (B) indicates the loreal pit (pit organ), situated between the eye and the nostril, which is the characteristic feature of pit vipers (hump-nosed viper and green pit viper). provided for the treatment of serious coagulopathic envenomation because of the risks of severe anaphylaxis and transfusion-related reactions to blood products. ${ }^{19}$ Regardless of the care taken in screening blood products, there is still a small, but significant, risk of blood-borne viral transmission associated with transfusion of FFP. Therefore, there are significant hazards associated with replacement therapy. Studies have shown that FFP is beneficial when provided after appropriate antivenom. ${ }^{19,20}$ However, because appropriate antivenom is not currently available for Hypnale envenomation, there are risks associated with treatment solely consisting of FFP transfusion, and thus the benefits and risks of replacement therapy should be clearly balanced when managing patients under these circumstances. However, if there is coagulopathy associated with bleeding risk, it may be beneficial to replace both FFP and cryoprecipitate. This is because thrombins like enzymes are the procoagulant toxins in Hypnale venom, and they simply consume fibrinogen rather than activating the clotting pathway. Therefore, in severe deficiency of fibrinogen, cryoprecipitate is an option.

Even though there is no convincing evidence that FFP would correct the VICC, as it contains many clotting factors including fibrinogen, factor V, factor VIII, and factor X, treatment with FFP would restore the clotting cascade. In addition, there is weak procoagulant activity in all 3 Hypnale venoms. For $\mathrm{H}$ zara, this is with $\mathrm{MCC}_{5}$ (minimum clotting concentration) of $5.5 \mu \mathrm{g} \cdot \mathrm{mL}^{-1}$ of plasma, ${ }^{21}$ and FFP may provide additional substrate for venom procoagulant action by generating microthrombi. Interestingly, this patient's INR was corrected from day 2 onward, but WBCT20 was positive for another day with increased APTT (Table 1). However, there is a positive association between VICC and TMA, ${ }^{22}$ as in our patient. Microthrombi produced in the process of VICC may lodge in renal vasculature and cause 
(A)

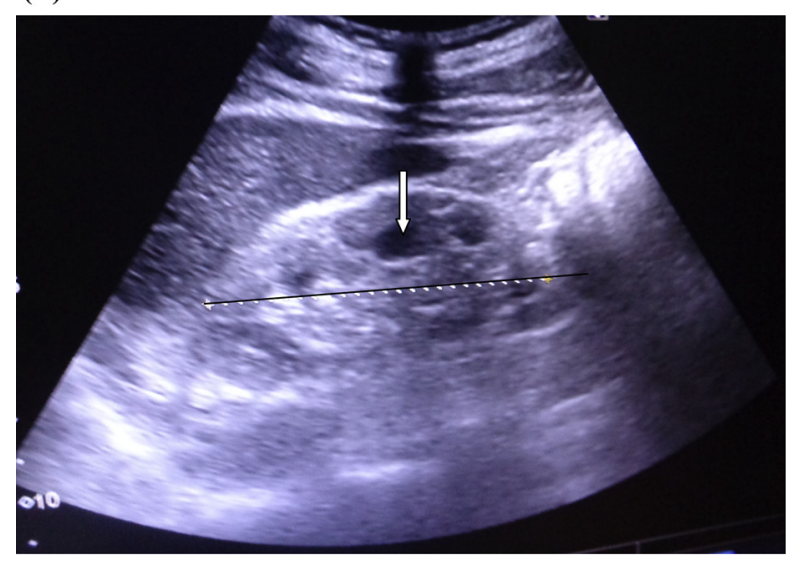

(B)

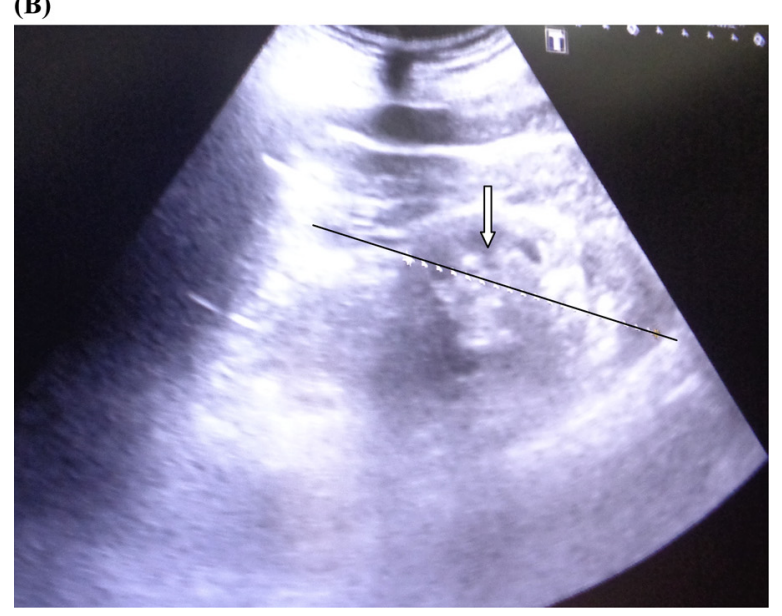

Figure 6. Renal ultrasonography on day 27 following snakebite showing features of acute kidney injury: swollen kidneys (indicated in black axis), reduced corticomedullary demarcation (indicated with white arrows), and increased renal echogenicity. A, Right kidney. B, Left kidney.

ischemia to kidneys, resulting in AKI. Morphological changes in red blood cells occur when they travel through the blocked vessels, and circulating platelets decrease due to dislodgement in fibrin mesh.

TMA is a clinical entity that includes the spectrum of hemolytic uremic syndrome (HUS) and thrombotic thrombocytopenic purpura (TTP). In TMA, if renal impairment is predominant without neurological involvement, it is considered HUS, whereas the presence of neurological manifestations with renal impairment is diagnosed as TTP. ${ }^{23}$ Thus, HUS is the most specific diagnosis in our patient because he predominantly had renal impairment that responded to several cycles of hemodialysis. HUS and TTP have previously been documented following $H$ hypnale bites. ${ }^{6,8,14}$ We managed HUS in our patient with 8 cycles of hemodialysis.

Therapeutic plasma exchange is another treatment modality for TMA in snakebites, ${ }^{24}$ but it was not suggested for our patient because his platelet counts were gradually improving (Table 1) and microangiopathic hemolysis detected from peripheral blood microscopy was also improving.

In hump-nosed viper bites, kidney injury may occur due to direct nephrotoxicity of venom, ${ }^{25}$ secondary (indirect) effects, or both. The indirect causes may be hemodynamic alterations caused by vasoactive mediators and cytokines, VICC, microangiopathic hemolysis, hemorrhage, and immunologic mechanism. ${ }^{26,27}$ All renal structures may be involved in the pathogenesis of AKI in hump-nosed viper bites. Acute tubular necrosis and cortical necrosis are the predominant renal histopathological changes. ${ }^{7,16,28}$ At the same time, diffuse cortical necrosis of the kidneys has been observed in autopsy findings after $\mathrm{H}$ zara bites. ${ }^{18}$ However, TMA is suggested as a plausible causative pathology of AKI in hump-nosed viper envenomation. ${ }^{13}$ According to our patient's clinical picture, we can assume that the renal failure may be due to continuous glomerular ischemia secondary to thrombosis in the renal vasculature. This clinical case further highlights the complex nature of Hypnale venom, which needs antivenom to counteract these severe effects.

Acknowledgments: Dr WDP Vidyarathna, Consultant Haematologist, Teaching Hospital, Ratnapura, Sri Lanka, is thanked for the evaluation of the peripheral blood smears. We thank the staff of the medical wards at Teaching Hospital, Ratnapura, Sri Lanka.

Author Contributions: Involvement of the patient management and literature search (RMMKNR, PEANR); snake identification and getting its morphological features (RMMKNR); drafting and writing the case history (RMMKNR, PEANR, SAMK); review and approval of the final manuscript (RMMKNR, PEANR, SAMK).

Financial/Material Support: None.

Disclosures: None.

\section{References}

1. De Silva A, Ranasinghe L. Epidemiology of snakebite in Sri Lanka: a review. Ceylon Med J. 1983;28(3):144-54.

2. De Silva A. Snakebites in Anuradhapura District. Snake. 1981;13(2):117-30.

3. Kasturiratne A, Wickremasinghe AR, de Silva N, Gunawardena NK, Pathmeswaran A, Premaratna R, et al. The global burden of snakebite: a literature analysis and modeling based on regional estimates of envenoming and deaths. PLoS Med. 2008;5(11):e218.

4. Maduwage K, Silva A, Manamendra-Arachchi K, Pethiyagoda RA. A taxonomic revision of the South Asian hump-nosed pit vipers (Squamata: Viperidae: Hypnale). Zootaxa. 2009;2232:1-28.

5. Maduwage K, Isbister GK, Silva A, Bowatta S, Mendis S, Gawarammana I. Epidemiology and clinical effects of hump-nosed pit viper (genus: Hypnale) envenoming in Sri Lanka. Toxicon. 2013;61:11-5.

6. Namal Rathnayaka RMMK, Kularatne SAM, Ranathunga PEAN, Rajapakse RPVJ, Ranasinghe JGS. Species specific clinical manifestations following hump-nosed 
pit viper (genus: Hypnale) envenoming in Sri Lanka. In: Sri Lanka Medical Association 130th Anniversary International Medical Congress. 13-16 July. 2017. Colombo, Sri Lanka. Ceylon Med J. (Suppl. 1). 2017;62:97.

7. Ariaratnam CA, Thuraisingam V, Kularatne SA, Sheriff MH, Theakston RD, de Silva A, et al. Frequent and potentially fatal envenoming by hump-nosed pit vipers (Hypnale hypnale and $H$ nepa) in Sri Lanka: lack of effective antivenom. Trans $R$ Soc Trop Med Hyg. 2008;102(11):1120-6.

8. Namal Rathnayaka RMMK, Ranathunga PEAN, Kularatne SAM. Kidney injury following envenoming by hump-nosed pit viper (Genus: Hypnale) in Sri Lanka: proven and probable cases. Trans $R$ Soc Trop Med Hyg. 2019;113(3):131-42.

9. Kularatne SA, Ratnatunga N. Severe systemic effects of Merrem's hump-nosed viper bite. Ceylon Med J. 1999;44(4): 169-70.

10. Namal Rathnayaka RMMK, Ranathunga PEAN. Acute kidney injury which leads to chronic kidney disease and death following hump-nosed pit viper (genus: Hypnale) envenoming. J Ratnapura Clin Soc. 2016:40-2.

11. Namal Rathnayaka RMMK, Ranathunga AN, Kularatne SAM, Rajapakse J, Ranasinghe S, Jayathunga R. Microangiopathic haemolytic anaemia following three different species of hump-nosed pit viper (genus: Hypnale) envenoming in Sri Lanka. Wilderness Environ Med. 2018;29(1): 94-101.

12. Joseph JK, Simpson ID, Menon NC, Jose MP, Kulkarni KJ, Raghavendra GB, et al. First authenticated cases of life-threatening envenoming by the hump-nosed pit viper (Hypnale hypnale) in India. Trans R Soc Trop Med Hyg. 2007;101(1): 85-90.

13. Herath N, Wazil A, Kularatne S, Ratnatunga N, Weerakoon K, Badurdeen S, et al. Thrombotic microangiopathy and acute kidney injury in hump-nosed viper (Hypnale species) envenoming: a descriptive study in Sri Lanka. Toxicon. 2012;60(1):61-5.

14. Namal Rathnayaka R, Ranathunga PAN, Kularatne SA. Thrombotic microangiopathy, haemolytic uremic syndrome and thrombotic thrombocytopenic purpura following humpnosed pit viper (genus: Hypnale) envenoming in Sri Lanka. Wilderness Environ Med. 2019;30(1):66-78.

15. Karunatilake H, Nayakarathna T, Atapattu S, Saparamadu T, Dharmasena S. Thrombotic microangiopathy and fibrinolysis after hump-nosed viper envenomation. Ceylon Med J. 2012;57(1):45-6.

16. Namal Rathnayaka RMMK, Nishanthi Ranathunga PEA, Ranaweera J, Jayasekara K, Kularatne SAM. Cardiac arrest and atrial fibrillation in a patient after hump-nosed pit viper (Hypnale hypnale) bite. Toxicon. 2018;148:33-9.

17. Namal Rathnayaka RMMK, Nishanthi Ranathunga PEA, Kularatne SAM, Jayathunga R, Kumarasinghe KDM, Jeganadan K. Epidemiology and haematological manifestations following hump-nosed pit viper (genus: Hypnale) envenoming in the region of Ratnapura (Sabaragamuwa Province - wet zone of Sri Lanka). J Ratnapura Clin Soc. 2017; 11:30-8.

18. Maduwage K, Kularatne K, Wazil A, Gawarammana I. Coagulopthy, acute kidney injury and death following Hypnale zara envenoming: the first case report from Sri Lanka. Toxicon. 2011;58(8):641-3.

19. Isbister GK, Jayamanne S, Mohamed F, Dawson AH, Maduwage K, Gawarammana I, et al. A randomized controlled trial of fresh frozen plasma for coagulopathy in Russell's viper (Daboia russelii) envenoming. J Thromb Haemost. 2017; 15(4):645-54.

20. Brown SG, Caruso N, Borland ML, McCoubrie DL, Celenza A, Isbister GK. Clotting factor replacement and recovery from snake venom-induced consumptive coagulopathy. Intensive Care Med. 2009;35(9):1532-8.

21. Maduwagea K, Hodgson WC, Konstantakopoulos N, O'Leary MA, Gawarammana I, Isbister GK. The in vitro toxicity of venoms from South Asian hump-nosed pit vipers (Viperidae: Hypnale). J Venom Res. 2011;2:17-23.

22. Isbister GK. Snakebite doesn't cause disseminated intravascular coagulation: coagulopathy and thrombotic microangiopathy in snake envenoming. Semin Throm Hemost. 2010;36(4):444-51.

23. Barbour T, Johnson S, Cohney S, Hughes P. Thrombotic microangiopathy and associated renal disorders. Nephrol Dial Transplant. 2012;27(7):2673-85.

24. Namal Rathnayaka RMMK, Nishanthi Ranathunga PEA, Kularatne SAM. Therapeutic plasma exchange (plasmapheresis) for the treatment of hump-nosed pit viper (Hypnale spp.) envenoming. J Ratnapura Clin Soc. 2018;3:20-6.

25. Silva A, Gunawardena P, Weilgama D, Maduwage K, Gawarammana I. Comparative in-vivo toxicity of venoms from South Asian hump-nosed pit vipers (Viperidae: Crotalinae: Hypnale). BMC Res Notes. 2012;5:471.

26. Chugh KS. Snakebite induced acute renal failure in India. Kidney Int. 1989;35(3):891-907.

27. Kanjanabuch T, Sitprija V. Snakebite nephrotoxicity in Asia. Semin Nephrol. 2008;28(4):363-72.

28. Varagunam T, Panabokke RG. Bilateral cortical necrosis of the kidneys following snakebite. Postgrad Med J. 1970;46(537):449-51. 